\title{
The \\ Student \\ and the Elder
}

\section{SunAMBee/Ann Marie Beals}

Wilfrid Laurier University

Ann Marie Beals/SunAMBee is a Two-Spirit IndigenousBlack L'nuwey - a mixed-blood African Nova Scotian and First Nation Mi'kmaq who hails from Mi'kma'ki territory of the Wabanaki Confederacy. Ann Marie is a graduate student at Wilfrid Laurier University, under the mentorship of Dr. Ciann L. Wilson and all their relations and ancestors. SunAMBee is a storyteller working on the ProclaimingOurRoots.com project. Stories from this project revolve around Indigenous-Black identity and relationships with Indigenous and Black communities, and Truth and Reconciliation. Ann Marie's research explores the health and wellbeing of Indigenous-Black communities in looking at the effects of colonial legacies of oppression and violence, ongoing structural inequities, and lack of acknowledgment of Indigenous-Black identity in the canadian settler nation-state. SunAMBee shares Indigenous-Black People's voices in stories of resilience, strength, self-assertion, and consciousness-raising. These sacred stories explore the lived experiences and knowledges of the health and wellbeing of IndigenousBlack communities. We are still here!
Keywords

Decolonial, Knowledge, Storytelling, Indigenous, Sovereignty 
We love our children.

We send our children out into the World hoping that they will make it,

We hope that our children will have a better life.

We send our children to the white man's school so they can get an education to make it,

We want them to make it,

We want them to have a better life.

But we know that the World is not always a welcoming place for our children outside our wombs,

In the bosom of Mother Earth.

But...

We have the rhythm of our words.

The rhythm of our drums.

The rhythm of our love.

We must share with our children the ways of Old.

We must teach them the rhythms.

Then, when they go out into the World to make it, They hear the rhythms in the beating of their hearts,

They hold the rhythms in their souls-to guide them when they are far from home in the white man's world.

This is a story of teaching the rhythms in a good way.

This is a story of the sharing our wisdoms, as we have for thousands and thousands of years.

This is a story to guide our children in the ways of the white man,

So they can be safe,

So they can be protected. 
The student is a youth in university.

The Elder is teaching the youth who believes they have made it because they are learning the ways of the white man.

The youth is on their way to a better life.

Yet the youth is troubled.

The Elder speaks of Old,

The rhythms of Mother Earth and the Cosmos.

\section{The Student and the Elder}

One day, a youth who had just come back from university for break, visited a beloved Elder in their village. The youth felt troubled and needed some advice.

The Elder sat down with the student on the riverbank, and said, "What troubles you?"

The student replied, "I have left my village to go to the school of the white man in the city, and I am learning the white man's ways."

"I am troubled because I am not farming and hunting and trapping and providing for my family, and I am failing in my task of taking care of my People."

The youth was learning the ways of their People before going to the white man's school, and they knew that it was part of their responsibility to take care of the People of the village, especially the Elders.

Yet, all their life the student saw the white man coming to their village. Sometimes he had a friendly shape, sometimes he was large and bloated, sometimes he was slithery and hidden. Sometimes he shifted his form so the student couldn't tell how the white man was coming to his People. Time and time again he saw the white man coming, so the student wanted to learn the white man's ways. 
"Hmmm..." said the Elder.

"I see the white man coming to our village to help our People, yet the People do not get better," continued the student.

The student pressed on, "My teachers at school tell me that it is okay, because the white man knows better because he has important jobs and makes lots of money."

"And the teachers tell me that the white man's way is the best way."

"So, should I learn the ways of the white man, even though he says things that I sometimes do not understand?"

"After all, the teachers in the white man's school know best how things should be done, and the white man knows best how to take care of us."

And though the student was quite sure that the white man's knowledge was the best knowledge, they were not so sure that they knew the true white man, as they remembered how the white man shifts and changes....

And the student thought out loud, "Though, I never see the same shape of white man come back, because he must be very busy. And because he is very smart."

Yet the student lamented, "But I do want our People to get better, and if the white man's ways are the best ways and if the white man's teachers are the best teachers, then..."

"And who are your teachers?" asked the Elder.

"My teachers are at the university," said the student.

And the Elder took the hand of the student and said, "Come here."

And the Elder placed the ear of the student on a Birch. 
"Listen to the tree. Do you not hear what the tree is saying?"

Rhythm Whispers...

And the Elder took the student's head and put it on the ground.

"Listen to the land. Do you not hear Mother Earth as she breathes?"

Rhythm Whispers...

And the Elder took the student's hand and placed it in the river.

"Listen to the river. Do you not hear the water as it rushes over the rocks?"

Rhythm Whispers...

And the Elder took the student's arms and spread them wide.

"Listen to the wind. Do you not hear the power of the Creator rush over your body?"

Rhythm Whispers...

And the Elder took the student's face and tilted it high to the sky.

"Listen to the universe. Do you not hear Grandmother Moon as she laughs with the Mighty Hunter?"

Rhythm Whispers...

And the student stated emphatically, "The trees and the land and the water and the wind and the moon and the stars cannot talk!"

"What can I learn from them?" the student asked, perplexed, "What can they teach me?"

And the Elder spoke their words: "There is knowledge in the white man's school, yes, but there is much 
knowledge to be learned from all the creations and relations around you."

"There are many ways to seek knowledge and many ways to learn," the Elder said in a whisper.

"So, are you saying that the white man should not come to our village to make us better?" asked the student. "Because the white man is very smart, and he can fix us."

"Are we broken?" asked the Elder.

"Well, some of our People are not happy," quipped the student.

"Why are they not happy?" the student asked, sadly quizzical.

"We were happy," said the Elder, "My grandmother told me the stories about the times."

And the Elder shared the stories with the student, who listened attentively.

"We were growing the Three Sisters, fishing the eel, trapping the rabbits, and hunting the deer and moose."

"But now, it is hard for us to do these things because we have lost our land."

"Now our People are sick, because we do not have the land to live on."

"But the white man has medicine!" interrupted the student. "He can help us!"

"Yes," said the Elder.

"The white man does have medicine, but it is not the medicine we need."

"Our medicine comes from the land." 
"And when the white man comes to help us, he does not ask us what kind of medicine we need."

"He says, 'it's my medicine and it is the best medicine... take it."'

"And when we ask the white man to sit with us and share with us as we tell our stories, he says he is too busy, and can only come to give us his medicine, which tastes awful as he forces our mouths open to take it."

"And when we try to show the white man what we know and what we have learned about our medicine, he does not see."

The student continued to listen intently as the Elder spoke...

"He does not see in his heart the good of the People of our village."

"We have lived here since the Great Spirit made us."

"We have lived here since Sky Woman was guided to Great Turtle's back."

"We take care of the land. We take care of the water."

"But we do not own the land and the water and the cosmos, like the white man thinks he does."

"The white man does not see that we are a strong People."

"We are the knowledge keepers of Creator."

"And when the white man speaks, it is from both sides of his mouth."

"It is hard to trust the white man."

"But, but, but," stammered the student, "The white man knows many big words and my teachers talk a lot about theory!" 
"Without theory, we couldn't do science!" said the student, exasperated by the Elder.

"And what is theory?" asked the Elder, shrewdly, ignoring the irritation in the student's voice.

"Theory explains how nature works," said the student, proudly beaming, remembering the A they got on their theoretical conceptual frameworks paper.

But in a lowered voice, the student revealed, "But not everyone knows about it."

"Ohhhhhhhhhhh, hahahahaha," laughed the Elder.

"I think I can explain a theory to you then," said the Elder, as they continued to chuckle.

"We are the Ancient Peoples, the First Peoples, and we know the ways of Mother and we use our ways of being and knowing for our People, like our medicines and our ceremonies."

"This is what we do, every day, in our lives."

"It is a theory of living with the land and all our relations!" cried the Elder, opening their arms to show the beauty and awe of their surroundings-of Mother.

The Elder continued in their teaching...

"With our theory, we care for all things."

"The spirit of Creator, all our relations, the land, the water, the four directions, all the creatures, even the rocks and the mountains."

"They are a part of our theory and how we come to know our World."

The student thought about all the Elder said.

"So, will the white man not come to help us anymore?" asked the student again, concerned. 
"Is he not allowed to come to help us because he talks about a different kind of theory?"

"I think my teachers might get angry."

And the student thought about how they could be punished for speaking out against the white man and the white man's teachings.

The student really wanted to do well in university, so that Grandmother would be proud. She had sacrificed so much for them to go to university and get an education to make it, to have a better life.

The Elder sat and thought... and thought... and thought...

"Hmmmm..." said the Elder, and puffed on their pipe.

The Elder finally spoke...

"I think the white man can come and be with us, because the white man does have some good words that we can use, and sometimes the white man comes to us with good thoughts."

"And the white man can be gifted with an Eagle Feather."

"Oh!" exclaimed the student. "An Eagle Feather! Wow!"

"But," spoke the Elder in a somber tone, "We must always remember that the white man has tried to kill us so that we no longer exist, and still tries to harm us and does not share with us or give back what he has stolen from us-our children, the land, our knowledge."

The Elder continued their teaching...

"We were here long before the white man, even though he tries to say that the land was empty when he arrived on these shores."

"So, he must come to us with a humble heart and be willing to sit with us in ceremony and the sharing 
circle and listen to our stories in our language..."

"... and not talk...though, this may be difficult for him."

“... and bring a gift of sacred tobacco."

"He must be willing to come and visit with us and listen to the words that the People of our village are willing to share."

"And not just one time, but many times."

"He must earn our trust."

"He must believe that our knowledge is true, as we use the knowledge our People have received from Creator in ways that we understand."

"He must understand that the knowledge we hold is for our wellbeing, our rights, and our ability to take care of ourselves and the land."

"We can show him how we do things, and he must honour our ways."

"He must honour our ceremony and counsel and honour our medicines that soothe and heal."

"He must honour our words when we speak of how our lives have come to be through the guidance and healing of the Elders."

"He must know that we are strong, and that we know how to be with the land in a good way."

"And because we have good hearts, we can guide and heal the white man too, because he is not in a good way."

"But, before we help the white man, he must come to understand why he thinks the way he does and be mindful of what he has done and how he continues to disturb and harm us."

“The white man thinks that we do not deserve to 
have a better life because he thinks we are lazy, or he thinks we drink too much or believes that we are stupid and we are different."

"He must speak and acknowledge that harm, and be in a good mind when he comes to us."

"He must not consider himself to be above us and he must understand that his knowledge is not better than our knowledge."

"He must give up his power."

"He must consult with the Elders."

"He must honour all our relations."

"These things, are part of his healing."

The Elder paused and thought some more.

“Hmmmm..."

And then continued...

"And the white man has laws that he is supposed to follow when he comes to us."

"But he does not always follow them, though he says he does."

"Forked tongues from a two-headed snake."

"And sometimes he does not tell us what he is doing, and that harms us."

"Sometimes he brings in outsiders who look like us, but do not know our ways of being and knowing..."

"...they say they are like us, and they are our relations, but it should be our People ...."

"...and if not us, then ask us if the outsiders can come in."

"The outsiders must be willing to learn our ways of 
being and knowing."

“The white man must be patient."

"When he takes, he must give back."

"And maybe the white man can come to understand that he is not just one, but a very small part of the many."

"We will show the white man the right ways."

"But he must come in a good way, with a good heart."

And the Elder sat quiet.

And out into the open air, as Grandmother Moon looked on, in a strong, passionate, and resolute voice, the Elder heard the student say, "I could do those things!"

"I can share my knowledge."

"I can sit and listen to the Elders."

"I am learning our ways of being and knowing."

"I can help heal our People."

"I am one of us."

"I come with a good heart."

And the Elder smiled, and said...

"Well! You are very brave, and I think you can go back into the world of the white man and learn the white man's ways, but keep our People and our ways in your head and in your heart."

Rhythm Whispers...

"Because you also have a job to do in the white man's world."

"You must share your stories with your teachers 
and the white man about the importance of being respectful when coming to our village."

"Our Elders and our People must be honoured and not disrespected."

"Teach them as you learn the good ways."

"Then you can bring knowledge to us, and take care of our People."

And the Elder explained in so many words about the rhythms that guide the student's heart, to be safe, to be protected in the white man's world.

"But beware," said the Elder, earnestly. "Take care and do not let harm come to you when your teachers and the white man try to make you think that your knowledge is not good knowledge and your stories are not good stories."

"I will teach you the sacred knowledge, but do not share the sacred knowledge."

"That is ours and ours alone."

And with a big grin, the Elder said, "So, I will help take care of the village while you are away. We all have our place in the village, and I like farming and hunting and trapping and fishing and providing for all the families."

The student grinned a big grin too, and was very grateful that the beloved Elder had shared with them the knowledge of the Ancestors. The knowledge of the Old. The knowledge of the Rhythms.

And the Elder took the student's hand once again as they walked back to the village.

And their hearts were full with joy and love, as Father Sun beamed down upon them.

The End. 


\section{Acknowledgements}

Wela'lin to our Ancestors who watch over us. Wela'lin to the Elders who guide, teach, and cajole. Wela'lin to M'sit No'kmaq who work in sustaining our Mother who is viciously under attack by those who seek to dominate and keep only for themselves. Welo'lioq 